\title{
Stanleyite, a new vanadium sulphate mineral from Peru
}

\author{
A. Livingstone
}

Department of Geology, Royal Scottish Museum, Chambers Street, Edinburgh EH1 1JF

\begin{abstract}
A BSTRACT. Stanleyite, a cobalt-blue mineral, occurs as efflorescent outgrowths on patronite from Cerro de Pasco, Minasragra, Peru. The determined composition is very close to the ideal formula $\mathrm{VOSO}_{4} \cdot 6 \mathrm{H}_{2} \mathrm{O}$ and yields an empirical formula of $\mathrm{V}_{1.01} \mathrm{O}_{1.01} \mathrm{~S}_{0.99} \mathrm{O}_{3.99}$ $5.78 \mathrm{H}_{2} \mathrm{O}$ on the basis of $\mathrm{O}=5$ in the anhydrous part. $\mathrm{X}$-ray powder data (31 lines) indexed on an orthorhombic cell give $a 12.12, b 9.71$, and $c 14.92 \AA$, cell volume $1755.8 \AA^{3}$ and $Z=8$. Refractive indices are $\alpha 1.505$, $\beta 1.519$, and $\gamma 1.533, \mathrm{D}$ is 1.95 (measured) and 2.01 (calculated), $\mathbf{H}=1-1 \frac{1}{2}$ (Mohs). Thermal analysis and $\mathrm{X}$-ray powder data show stanleyite to be quite different from minasragrite (the pentahydrate) which it clearly mimics. Associated minerals are potassium alum, pyrite, and quartz.
\end{abstract}

IN 1922 the Royal Scottish Museum exchanged specimens with the British Museum (Natural History) for a suite of meteorite casts and minerals. Included in the exchange material was a specimen labelled 'Minasragrite on decomposing patronite, Minasragra, Cerro de Pasco, Peru'. This material was received by the British Museum (NH) from the Peruvian Government in 1917. X-ray diffraction examination of the 'minasragrite' revealed a powder pattern completely incompatible with the minasragrite $\left(\mathrm{VOSO}_{4} \cdot 5 \mathrm{H}_{2} \mathrm{O}\right)$ data of Smith and Marinenko (1973). The pattern could not be matched with that of any known mineral but closely fitted the unindexed data for the synthetic higher hydrate $\mathrm{VOSO}_{4} \cdot 6 \mathrm{H}_{2} \mathrm{O}$.

The new species, and name, have been approved by the International Mineralogical Association Commission on New Minerals and Mineral Names. Stanleyite is named after the journalistexplorer Henry Morton Stanley (1841-1904) who, on 10 November, 1871 , found Dr David Livingstone in Africa. It is implicit in some mineral names, when paired, that compositional or structural similarities exist, as in the case for adamite and eveite, but it must be stressed that no link in this manner occurs between livingstonite and stanleyite. However, in 1858, Dr David Livingstone presented the Royal Scottish Museum with a collection of African rocks and minerals and therefore it seems reciprocally appropriate to honour mineralogically the man who immortalized the phrase 'Doctor Livingstone I presume' (a phrase the author has had to live with for many years!).

Physical properties. Stanleyite occurs as an aquamarine to deep cobalt-blue efflorescence on bluishblack, loose, fine-grained patronite or as sporadic fragments up to $1.5 \mathrm{~mm}$ across, disseminated throughout the sample. Optically, the stanleyite fragments appear to be aggregates of minute plates although scanning electron microscopy reveals that the grains possess very ragged surface features (fig. 1). Occasionally portions of individual grains have a 'desert rose' configuration with units of plates stacked in parallel or sub-parallel position. The units are randomly orientated with respect to each other. Due to the extremely fine-grained nature and softness, cleavage was not detectable. Stanleyite has a white streak and Mohs hardness of 1-112. The measured specific gravity is 1.95 and on the basis of the empirical formula the calculated value is 2.01 . The new mineral is optically positive with a large $2 \mathrm{~V}$ and no dispersion. Refractive index measurements yielded $\alpha 1.505, \beta 1.519$, and $\gamma 1.533$, and pleochroism is moderate with absorption $\mathrm{X}=\mathrm{Y}$ blue, $>\mathrm{Z}$ very pale-blue to colourless. The refractive indices and specific gravity are slightly

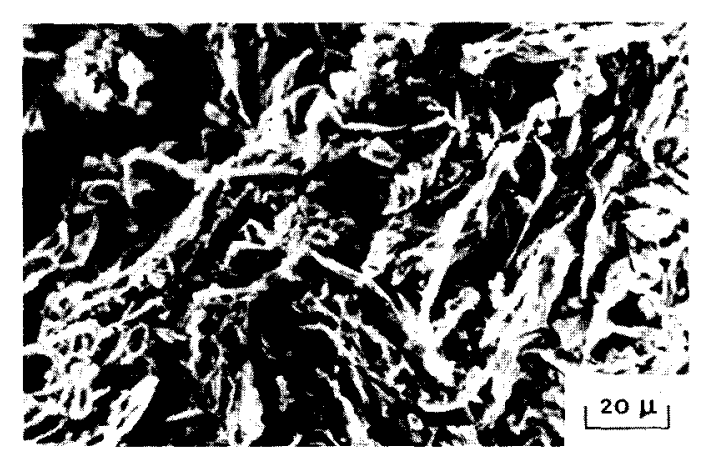

FIG. 1. Scanning electron micrograph of typical stanleyite grain surface.

(C) Copyright the Mineralogical Society 
lower than those values reported by Smith and Marinenko (1973) and most probably reflect the extra water molecule in the structure. A few minute lath-like fragments extinguish at up to $15^{\circ}$ to the length. Under long- or short-wave ultra-violet light no fluorescence was observed. Stanleyite is instantly soluble in cold water and very dilute acids, and slowly soluble in alcohol.

$X$-ray powder data. Minute single grains were $\mathrm{X}$-rayed using $\mathrm{Cu}-K \alpha_{1}$ radiation and all the patterns produced are identical both in respect of $d$-spacings and relative intensities (except for slight ittensity variations in lines which show preferred orientation effects). Even with very fine grinding, and extreme softness, it was not possible to completely eliminate preferred orientation nor was it practicable to include an internal standard. The powder data, presented in Table I, can be reasonably indexed on an orthorhombic cell with $a 12.12, b 9.71$ and c $14.92 \AA$; cell volume is $1755.8 \AA^{3}$ and $Z=8$. Ballhausen et al. (1968) synthesized two orthorhombic unstable forms of $\mathrm{VOSO}_{4} \cdot 5 \mathrm{H}_{2} \mathrm{O}$ and a monoclinic stable form identical with minasragrite. In the absence of single crystal data for stanleyite, and bearing in mind the inclined extinction previously noted, monoclinic symmetry cannot be ruled out.

Powder diffraction data for stanleyite fit very closely that given by Tudo (1965) for $\mathrm{VOSO}_{4}$. $6 \mathrm{H}_{2} \mathrm{O}$ and incorporated in the JCPDS under set 19-1412. Tudo's data contains several extra lines not found in the stanleyite pattern and between $d$ 6.06 and $3.09 \AA$ eleven equivalent lines reported by Tudo average $1.7 \%$ higher spacings than those of

TA B LE I. X-ray powder data for stanleyite

\begin{tabular}{|c|c|c|c|c|c|c|c|}
\hline$d_{\text {meas }}$ & $I_{\text {est }}$ & $h k l$ & $d_{\mathrm{cale}}$ & $d_{\text {meas }}$ & $I_{\text {est }}$ & $h k l$ & $d_{\text {calc }}$ \\
\hline 9.71 & 5 & 010 & 9.71 & \multirow{3}{*}{$2.350 b$} & \multirow{3}{*}{10} & 510 & 2.352 \\
\hline 6.06 & 5 & 200 & 6.06 & & & 404 & 2.352 \\
\hline 5.86 & 5 & 012 & 5.91 & & & 141 & 2.351 \\
\hline 4.98 & 90 & 003 & 4.973 & 2.169 & 5 & 520 & 2.169 \\
\hline 4.69 & 80 & 202 & 4.704 & 2.086 & 10 & 522 & 2.083 \\
\hline 4.41 & 60 & 013 & 4.426 & \multirow{2}{*}{2.030} & \multirow{2}{*}{10} & $\int 044$ & 2.035 \\
\hline 4.20 & 100 & 212 & 4.233 & & & $\{504$ & 2.033 \\
\hline 4.02 & 15 & 300 & 4.040 & 1.962 & 10 & 611 & 1.961 \\
\hline 3.81 & 60 & 220 & 3.789 & 1.908 & 5 & 612 & 1.912 \\
\hline \multirow{2}{*}{3.73} & 60 & $\{310$ & 3.730 & \multirow{2}{*}{1.802} & \multirow[t]{2}{*}{5} & $\left\{\begin{array}{r}533 \\
345\end{array}\right.$ & $\begin{array}{l}1.808 \\
1.708\end{array}$ \\
\hline & & $\{004$ & 3.730 & & & 245 & 1.798 \\
\hline 3.23 & 10 & 030 & 3.237 & \multirow{2}{*}{1.754} & \multirow{2}{*}{5} & $\int 525$ & 1.754 \\
\hline 3.09 & 20 & 320 & 3.105 & & & $\{218$ & 1.753 \\
\hline 3.04 & 10 & 321 & 3.040 & 1.702 & 5 & 631 & 1.702 \\
\hline 2.94 & 5 & 024 & 2.958 & 1.661 & 5 & 712 & 1.662 \\
\hline \multirow{2}{*}{2.85} & 10 & $\{230$ & $\{2.855$ & \multirow{2}{*}{1.555} & \multirow{2}{*}{5} & $\{129$ & 1.556 \\
\hline & & 015 & $\{2.852$ & & & 261 & 1.555 \\
\hline 2.74 & 20 & 304 & 2.741 & & & 148 & 1.468 \\
\hline 2.62 & 5 & 323 & 2.634 & 1.467 & 5 & $\{812$ & 1.468 \\
\hline 2.486 & 5 & 006 & 2.487 & & & 607 & 1.466 \\
\hline 2.427 & 5 & 040 & 2.428 & & & & \\
\hline
\end{tabular}

Camera diameter $114.6 \mathrm{~m}$. Cu-K $\alpha_{1}$ (Ni filter) $b=$ broad line. stanleyite. Smith and Marinenko (1973) noted that $d$ spacings reported by Tudo for $\mathrm{VOSO}_{4} \cdot 3 \mathrm{H}_{2} \mathrm{O}$ were consistently smaller by about $0.8 \%$ than those found by the two authors for the same phase. Other differences are also apparent, for under normal laboratory conditions Tudo found the hexahydrate to be the most stable form, whereas Ballhausen $e t$ al. (1968) found that only single crystals of the pentahydrate were stable. On all stanleyite powder patterns there was no evidence for any of the strongest minasragrite lines, although it is known that dehydration of higher vanadium sulphate hydrates to lower hydrates is possible. Likewise, Smith and Marinenko (1973) did not find evidence for the partially dehydrated phase $\mathrm{VOSO}_{4} \cdot 3 \mathrm{H}_{2} \mathrm{O}$ in their minasragrite work.

Chemistry. Preparation of X-rayed single grains for electron-probe microanalysis proved more difficult than expected. This was not due to the extreme softness which produced undercutting and low profiles relative to the resin surface but because of unexpected reactivity with various resins tried. The reaction was rapid and produced a brownish halo of crystallites and bubbles around the stanleyite grains. Once the haloes formed the grains easily plucked out during polishing.

Predictably, stanleyite constantly lost water, even with a defocused beam, during electron-probe microanalysis, which was undertaken with a Cambridge Instruments Geoscan V with standardization on vanadium metal, and pyrite for sulphur. Results are presented in Table II and the normalized stanleyite composition is derived from a combination of electron-probe results and thermogravimetric analysis. Using the latter technique it was possible to determine the water and $\mathrm{SO}_{3}$ contents directly and these account for $67 \%$, by weight, of the analysis. After deduction of minor constituents the empirical formula is calculated from $\mathrm{VO}_{2}, \mathrm{SO}_{3}$ and $\mathrm{H}_{2} \mathrm{O}$ and is $\mathrm{V}_{1.01} \mathrm{O}_{1.01}$ $\mathrm{S}_{0.99} \mathrm{O}_{3.99} \cdot 5.78 \mathrm{H}_{2} \mathrm{O}$ on the basis of 5 oxygens in the anhydrous part. The ideal formula can be expressed as $\mathrm{VOSO}_{4} \cdot 6 \mathrm{H}_{2} \mathrm{O}$.

For the thermal analysis a Stanton-Redcroft TG-770 micro-thermobalance was used at a heating rate of $15^{\circ} \mathrm{C}$ per minute and the thermogravimetric (TG) and differential thermogravimetric (DTG) curves are depicted in fig. 2. Based on a determined water loss of 38 wt. $\%$ the empirical formula calculations yield $5.8 \mathrm{H}_{2} \mathrm{O}$ molecules whereas the ideal formula, for six water molecules, yields a theoretical value of $39.8 \% \mathrm{H}_{2} \mathrm{O}$. A tentative interpretation of the TG and DTG curves, based on a one milligramme sample, suggests a stepwise loss of water with the last molecule being driven off between 160 and $340^{\circ} \mathrm{C}$. In fig. 2 the water loss has been theoretically divided into sixths, and the 
STANLEYITE, A NEW MINERAL

T A BLE II. Electron-probe microanalyses and stanleyite composition

\begin{tabular}{|c|c|c|c|c|c|c|c|c|c|c|c|}
\hline $\begin{array}{l}\text { Analysis } \\
\text { number }\end{array}$ & 1 & 2 & 3 & 4 & 5 & 6 & 7 & 8 & 9 & 10 & 11 \\
\hline $\mathrm{V}_{2} \mathrm{O}_{4}$ & 35.1 & 35.8 & 35.3 & 38.1 & 37.4 & 33.8 & 38.2 & 39.8 & 35.7 & 36.6 & 30.6 \\
\hline $\mathrm{SO}_{3}$ & 32.5 & 33.4 & 31.2 & 36.2 & 35.4 & 33.9 & 34.8 & 38.1 & 36.6 & 34.7 & 29.0 \\
\hline $\mathrm{SiO}_{2}$ & 1.4 & 0.4 & - & - & - & 0.1 & 0.1 & 0.2 & - & 0.4 & 0.3 \\
\hline $\mathrm{Al}_{2} \mathrm{O}_{3}$ & 0.4 & 0.1 & 0.2 & 0.3 & 0.3 & 0.2 & 0.6 & 0.4 & 0.5 & 0.3 & 0.2 \\
\hline $\mathrm{TiO}_{2}$ & 0.1 & - & - & - & 0.1 & - & - & - & - & 0.1 & 0.1 \\
\hline $\mathrm{FeO}$ & 0.1 & 0.3 & - & - & - & 0.1 & - & 0.8 & 0.3 & 0.3 & 0.2 \\
\hline $\mathrm{MgO}$ & 0.2 & - & - & - & - & - & - & - & - & 0.2 & 0.1 \\
\hline $\mathrm{NiO}$ & 0.2 & 0.6 & - & - & - & - & - & - & - & 0.4 & 0.3 \\
\hline $\mathrm{CaO}$ & 0.1 & $\ldots$ & - & 0.1 & - & - & - & - & - & 0.1 & 0.1 \\
\hline $\mathrm{K}_{2} \mathrm{O}$ & 0.2 & - & 0.2 & 0.2 & 0.3 & 0.5 & 0.5 & 0.7 & 1.6 & 0.5 & 0.4 \\
\hline \multirow[t]{4}{*}{$\mathrm{Cl}$} & 0.2 & 0.1 & 0.1 & 0.1 & - & 0.1 & - & 0.1 & 0.1 & 0.1 & 0.1 \\
\hline & 70.5 & 70.7 & 67.0 & 75.0 & 73.5 & $* 68.7$ & 74.2 & 80.1 & 74.8 & 73.7 & 61.4 \\
\hline & & & & & & & & & & $\mathrm{H}_{2} \mathrm{O}$ & 38.0 \\
\hline & & & & & & & & & & & 99.4 \\
\hline $\mathrm{V}_{2} \mathrm{O}_{4} / \mathrm{SO}_{3}$ & 1.08 & 1.07 & 1.13 & 1.05 & 1.05 & 0.99 & 1.09 & 1.04 & 0.97 & 1.05 & 1.05 \\
\hline
\end{tabular}

Analyses 1-5 and 8 and 9 are single spot analyses on separate grains, 6 and 7 are two spots on same grain. Analysis 10 is the average of 1-9 results.

Analysis 11. Stanleyite composition derived from 'anhydrous' analysis 10 normalized against $\mathrm{SO}_{3}$ result from thermal analysis, and $\mathrm{H}_{2} \mathrm{O}$.

* Analysis shows $0.1 \% \mathrm{MnO}$. - indicates not detected.

first two molecules appear to be rapidly expelled between $\mathrm{A}$ and $\mathrm{B}$ on the DTG curve. The next three molecule's expulsion is somewhat indeterminate whereas the most strongly bonded, last molecule, is slowly removed between $\mathrm{C}$ and $\mathrm{D}$ over the temperature range $160-340^{\circ} \mathrm{C}$. Of the $\mathrm{SO}_{3} 27$ wt. \% is expelled between 340 and $600{ }^{\circ} \mathrm{C}$ which is slightly low when compared with the theoretical value of $29.5 \%$. From the heating curves it is apparent that not all the $\mathrm{SO}_{3}$ is expelled until $\mathrm{V}^{4+}$ is oxidized to $\mathrm{V}^{5+}$, which accounts for a gain of $1.5 \%$. A further weight loss occurs between 800 and $900{ }^{\circ} \mathrm{C}$ and is assumed to be the remainder of the $\mathrm{SO}_{3}$, the total weight reduction due to $\mathrm{SO}_{3}$ expulsion being $29 \%$. The stanleyite heating data are markedly different from those of minasragrite where the water appears to be completely removed at $150^{\circ} \mathrm{C}$ and $\mathrm{SO}_{3}$ at $600^{\circ} \mathrm{C}$ (Smith and Marinenko, 1973).

Heating tiny, crushed stanleyite grains between 35 and $70^{\circ} \mathrm{C}$ for varying periods between 10 and 30 minutes, followed by $\mathrm{X}$-raying the products, failed to convert the hexahydrate to the pentahydrate, or even trihydrate. At the lower temperatures, and with short heating times, the stanleyite structure remained apparently unchanged as opposed to longer times (low temperatures) or higher temperatures (short time) when the structure collapsed.

An infra-red scan shows characteristic water and $\mathrm{SO}_{3}$ absorptions with the latter occurring at 1190 , 1100,1015 , and $640 \mathrm{~cm}^{-1}$.

Assemblage. The poorly crystallized patronite on which stanleyite occurs contains finely disseminated pyrite and an abundant $\mathrm{V}, \mathbf{K}$, and S-bearing unidentified phase. Potassium alum occurs freely as a very minor constituent and the patronite contains a trace of quartz. An X-ray fluorescence qualitative scan of part of the loose

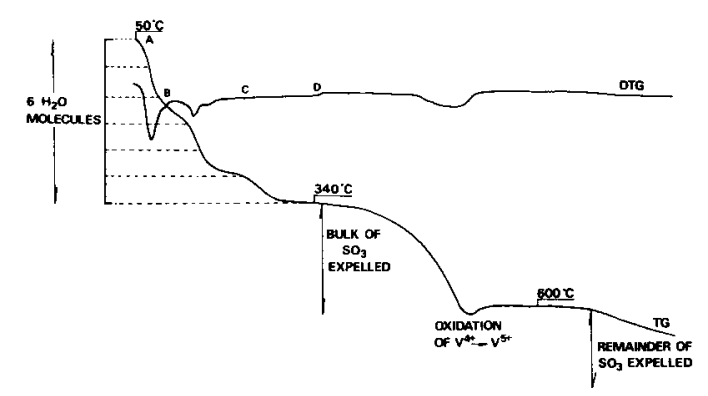

FIG. 2. Thermogravimetric (TG) and differential thermogravimetric (DTG) curves for stanleyite. 
sample shows Mo to be present at a high traceelement concentration level. Baumann (1964) reported molybdenite and bravoite as occurring with the patronite in the deposits at Minasragra, and nickel was also detected in the stanleyitebearing sample. The loose, friable material would appear not too dissimilar from the patronite detailed by Baumann and the stanleyite efflorescent nature is identical to that of minasragrite although there is no evidence, at the present time, for or against stanleyite developing from the former mineral.

Type material is registered under number 1922.11.6 and is deposited in the General Mineral Collection, Department of Geology, Royal Scottish Museum.
Acknowledgements. The author is indebted to Dr D. J. Morgan of the Institute of Geological Sciences, Geochemical Division, for the thermal analysis and to $\mathrm{Mr}$ J. Addison of the Institute of Occupational Medicine for the SEM photograph and infra-red scan. Mr D. A. Carrie very patiently undertook the difficult sample preparation for electron-probe microanalysis.

\section{REFERENCES}

Ballhausen, C. J., Djurinskij, B. F., and Watson, K. J. (1968) J. Am. Chem. Soc. 90, 3305-9.

Baumann, I. H. (1964) Neues Jahrb. Mineral. Abh. 101, 97-108.

Smith, M. L., and Marinenko, J. (1973) Am. Mineral. 58, 531-4.

Tudo, J. (1965) Rev. Chim. Minerale, 2, 53-117.

[Note added in proof. Recent work on synthetic $\mathrm{VOSO}_{4} \cdot 6 \mathrm{H}_{2} \mathrm{O}$ (Tachez and Theobald, 1980) has shown the compound to be triclinic with $a 7.47, b 10.137$, and $c 6.20 \AA$ and $\alpha 101.9^{\circ}, \beta 95.54^{\circ}$, and $\gamma 92.12^{\circ}$. Powder data for this compound (Tachez et al., 1976) are very similar to those of stanleyite except for nine additional lines, of intensity 20 or more, between 9.95 and $2.169 \AA$. Stanleyite may well be a triclinic polymorph. The parameters above yield a cell volume of $456.8 \AA^{3}$, and on the basis of the empirical formula and $Z=2$ the calculated density is $1.94 \mathrm{gm} / \mathrm{cm}^{3}$. This value is in far better agreement with the determined figure than that calculated on an orthorhombic cell, and all the stanleyite lines index with the above parameters.

Tachez, M., and Theobald, F. (1980) Acta Crystallogr. B36, 2873-80. and Trouillot, G. (1976) J. Appl. Cryst. 9, 246.] 